\title{
Utilizing the Relationship between Education and Freedom as a Tool for Poverty Alleviation
}

\author{
Umar Tela \\ Department of Banking and Finance, Federal Polytechnic Nasarawa, Nasarawa State. Nigeria
}

\begin{abstract}
The theories of Adler (1982), Greene (1988), Illich (1970) \& Dewey (1907) had shaped discourse on education and promotion of free society. In this study, these theories were analyzed, compared and contrasted as well as discussing their underlying perspectives as regards societal change and promotion of free society. I argue that while these theories seem divergent in their views on societal change and promotion of free society through education, all of them are critical and relevant to accomplishing a societal change. I also argue that, since Nigeria has high rate of poverty, it is important that technology education system is reformed where the formal traditional and informal educational systems are harmonized. Through this, the poor will benefit from the unlimited opportunities available in the society as a result of the rapid development of technology
\end{abstract}

Key Words:Education, Freedom and Poverty Alleviation

\section{Introduction}

Education and learning philosophies have guided development of educational curriculum and management of school systems (illich, 1970). The debate on the suitable education philosophies has centered and deep rooted in the discourse of freedom and the power of choice. The divergent views have been on the concept of freedom and the implementation of educational methods without limiting individual freedom. Some of the thinkers view freedom as a concept that connotes discipline and responsibility. Others think there is a critical relationship between societal development and personal development hence it is important that personal development goes parri-pasu with societal development, thus education and learning should reflect societal development.

Among this group of thinkers, individual freedom is dependent on the society hence education and learning should be organized and implemented in any way that there is a strong linkage between society and individuals. Yet, a group view freedom as individual liberty that entails freedom to choose that is encumbered by the societal development. In other words, freedom should be total and not restricted or limited in any form. Hence, the group are of the view that methods of implementing education and learning as it is structured today that requires classroom attendance and total adherence to curriculum limits individual freedom and requires complete review. These divergent views led to their classifications into different schools of thought that include liberal (traditionalists), progressive (pragmatic) and radical (critical) are broadly the three major philosophies in education and learning. The central debate among the three theories in the field include Greene (1988), Illich (1970), Adler (1982) \& Dewey (1907) on advancing education and learning that promotes freedom and its relationship with the society.

\section{Education and freedom: Greene's view}

Greene can be described as one of the proponents of the progressive school of thought and in her writing promoted the need for pragmatic approach to the issue of freedom and education. According to Greene (1988: 1) personal freedom is usually referred to as "self-dependence and self-determination" and has nothing to with the interconnectedness of the community. However she tends to disagree that personal freedom is just as described above but, also involves the freedom to make choices and the ability to "accomplish what one chooses to do"(Greene 1988: 2-3). Nevertheless the power of choice is based on intelligent knowledge of the circumstances surrounding the choice and the consequences of the choice. Buttressing her point further, she argues that freedom is not just restricted to the "capacity to choose" but a "matter of power to act to attain one's purpose" which entails "intelligent choosing..."(Greene 1988: 4-5). She summed her view by asserting, "freedom ought to be conceived of as an achievement within the concreteness of lived situation rather than a primordial or original possession" (Green 1988: 4-5). The meaning of the summation is that freedom should not be viewed based on the slogan of 'born free' which translates to original possession but should be viewed as an achievement. This can only be achieved through pragmatism and readiness to make free choices based on the present challenges.

In order to achieve this, Greene argues that it requires education, which is the means through which "individuals can be provoked to reach beyond themselves in their inter-subjective space," (Greene 1988: 12). 
Through education, knowledge and empowerment, which are basic tools for in the power of choices and accomplishment, will be acquired. However, while education is important for the pursuit and attainment of freedom, it is quite absurd to suggest that personal freedom has no interconnection with the community or the society. Greene argues that separation of personal freedom from the community is tantamount to alienation of "persons from their own landscape... (and) preventing one to reach with others in seeking open possibilities" (Greene 1988: 22).

In Greene's view, education should be progressive and should accommodate personal freedom as well as ensuring that such freedom to choose is entrenched within the development of the community. Hence she argues that personal freedom in education that is pursued in isolation will alienate the individual from the community. Such personal freedom to choose in education should not be exclusive of the development or changes in the society. It should come with discipline and responsibility within the community as well as pragmatic in order to identify the changes and possibilities within the society.

\section{No Freedom Without Discipline and Responsibility}

Adler (1982) argues that freedom cannot be discussed without a sense of discipline and responsibility. $\mathrm{He}$ asserts that "true freedom is identical to duty" hence necessary to view discipline as "indispensable to freedom" (Adler 1982). Reflecting on education and freedom, he argues that elective system in schools "defeats the very purpose of liberal education" (Adler 1982). Allowing students the right to choose what to study through the elective system reflects the freedom in the educational system. However, Adler argues that liberal education which he is promoting is only "developed when a curriculum can be devised which will be the same for all men as it will consists in it those moral and intellectual disciplines which liberate men, cultivating their thought, specifically rational power to judge freely and exercise free will". Adler's argument suggests that personal freedom should not be exclusive of the community but one that prepares the students morally and intellectually to be "citizen of a democratic society" (Adler 1982). Adler and Greene agree that education and freedom should not be pursued in a manner that it alienates the students from the community. However, their disagreement is on the extent of freedom people should have in choice of education. While Greene argues that freedom of choice should be based on the societal development and not necessarily for the sake of being free, Adler thinks that such freedom to choose in education should not arise in the first place since education is designed to achieve a peaceful global community. Adler (1982) concludes that man's education "prepares him to do his duty" and that education is the tool that disciplines man to identify such duties and his ability to accomplish them.

\section{Freedom to Choose in Education Should Reflect Societal Changes}

In Dewey's view, freedom and education should not be dependent on the recognition that freedom of choice in education reflects the societal change and needs. Such personal freedom should go hand in hand with discipline. He contended that too much freedom to choose in education has led to distinction between learning and training in education system, thereby creating gulf between "professionals" and "workers" (Dewey 1907). He argues further that freedom in education should be handled in a way that it will be inclusive rather than exclusive of the societal development that may lead to "development of the personality" leaving out the societal development (Dewey 1907: 12). In view of this, Dewey propose that education should undergo "complete transformation" just as "our social life has undergone through thorough and radical change" to reflect and keep pace with the changes in the society. He concluded that education should not be seen as "culture" and "development of personality" which those who pass through it view it as a "practical tool" to eke out a living (Dewey 1907: 9) but as a tool that will lead to entrenchment of positive societal values.

In comparison with the views of Greene and Adler, Dewey agrees that freedom of choice cannot be total but comes with responsibility and discipline. Furthermore, education plays a development of the personality towards societal development. In sum, Dewey strongly argues that there is no distinction between personality development and societal development. Both have strong linkage and restriction and limitation of individual freedom has direct impact on societal development vice versa.

\section{Freedom to Choose in Education Should be Total}

Illich (1970) argues that freedom of choice in education should be total without any strings such as discipline and responsibility attached. Such education should not be institutionalized, as is currently the practice. Advancing reasons why schools should be disestablished, illich argues that equal obligatory education "must be recognized as at least economically unfeasible" (Illich, 1970:6). In sum, Illich's view is that equal education that is made obligatory is socially polarizing, increases expenditure and destructive. However he agreed that "equal education is indeed both desirable and feasible goal" but is of the view that making it an obligation will create confusion in the society (Illich, 1970:6). In his view "institutionalization of values" which educational managers argue is one of the main reasons why education system should be established only leads to “...physical pollution, social polarization and psychological impotence” (Illich, 1970: 1). He argued that 
establishment of school and its funding further impoverish the poor and an advantage to the rich (Illich, 1970). In his view, "equal education opportunity is indeed both desirable and a feasible goal..." but should not in any way be made an obligation. Such obligation according to his argument limits individual choice of education. Illich (1970) views established education as detrimental to positive societal development hence he propose a disestablishment of schools in order to give individuals the full freedom of choice. Aside from limiting individual freedom, Illich argues further that institutionalized schools have failed to improve the education of the poor as often argued by policy makers as a reason for institutionalized school despite the huge investment. This argument to some extent might be appealing and feasible looking at educational standard across the globe especially in the developing country where education investment is sourced from lean budgetary allocation and foreign aids. For instance, one of the reasons of the institutionalization of the Universal Basic Education (UBE) in Nigeria is due to the overstretching of the facilities available to the schools, which has incapacitated the schools to deliver the right education and close the gap between the poor and the rich. Nevertheless this may not be enough argument to de-establish school as Illich argues rather it could be a pointer to areas that needs improvement. However, Illich is convinced that disestablishment of schools can only be effective when a law is made that forbid "discrimination in hiring, voting, or admission to centers of learning based on previous attendance at some curriculum" (Illich, 1970:7). This argument supports the need to support "competence for a function or role" (Illich 1970: 7) as against basing recruitment and admissions decision on paper certificates. In support of his argument for de-schooled society, Illich argues that such society without established school recognizes "two faced nature of learning" that includes skill drill and other kind of learning (Illich 1970:9). Illich accused the established school system of lacking in skill instruction as programs meant to improve skills are attached to other programs, which in his views are not relevant. This he attributed to the use of curricular rather than learning. For instance, in Nigerian technical education curricular, students are made to study subjects in liberal arts while students in business education are compelled to study and pass subjects in sciences. This learning procedure is what Illich thinks is quite irrelevant. This procedure only encourages students to only work towards getting a grade on the subject rather than learning the subject, as it is quite irrelevant to main skill the student is pursuing. In addition, schools, Illich argued that,false public utilities that present false impression that it is open and equal to all rather, it is restrictive and open to only those "who consistently renew their credentials" (Illich 1970: 27). Persons that are acquiring other forms of learning outside the school system are left out. A public utility is not supposed to be restrictive in nature and not based on any curricular. In place of established schools, Illich proposed a different learning concept that does not compel a submission of "obligatory curriculum" and does not discriminate based on possession of certificate or diploma. The new concept of learning should make learning be "readily available to the public and designed to spread equal opportunity for learning and teaching" (Illich 1970:33). This form of learning concept is not restrictive and allows the use of available technologies. Illich argued that instead of the huge investment in established schools, such investment could be directed towards building an "unlimited library of prerecorded tapes, with outlets even in remote villages as well as an ample supply of empty tapes" (Illich 1970:34). In order to facilitate or promote this new form of education and learning concept, a network of tape recorders should be built that is radically different from the then network of television ${ }^{1}$ that should be able to provide reference services to educational objects, promote skill exchange, encourage peer matching and provide reference services to educators-at-large (Illich 1970:34). No doubt, this is what is obtained today as Internet has provided platforms for learning and education. Although Illich argument that society should be deschooled can be viewed as very radical since it went directly opposite what is widely believed at the period, he may have predicted correctly the role technologies will play in learning and education. Also, Illich argued that part of the solution is the review of the "very idea of publicly prescribed learning rather than the methods used in its enforcement" (Illich 1970: 29). While this argument may appear plausible, it questions the very foundation of traditional methods of learning and the concept of curricular in schools, as it is presently obtainable. No doubt curriculum as drawn up by educational authorities restrict and direct the students to what the authorities wants them to learn, yet it standardize learning and education across schools. The critical question will be what will be the consequences when standard is thrown out for the sake of freedom? While freedom is essential and crucial, it is important that the standard of education is not compromised. This inevitably leads one to another crucial question on the subjective meaning of standard of education. In Illich's view, the standard being given as a reason for huge investment in education and publicly prescribed learning has not been used to close the education disparity between the 'haves and the have not' in the society. Hence his grouse with the system that is insisting on obligatory education is its failure to use education to achieve equality or at least close the gap between the rich and the poor. However, it may be difficult to achieve education that does not in any way limit freedom even

\footnotetext{
${ }^{1}$ At the 1970 when Illich advanced this argument, Internet is still a dream and few (very insignificant) people would have thought the Internet would develop and become part of our everyday life. Today, schools make use of the Internet technologies to create a virtual classroom and allow students the freedom to choose when to learn and what to learn. However the schools are bound by a curriculum created by the schools that is approved by educational authorities.
} 
with Illich's suggestion of using a web of network. For instance, most of the schools today are hooked up to the web of network and at the same time running a traditional class room based learning while others are solely based on the web of network with little or no contact with the traditional classroom method of learning. Yet, there is still quite a gap between the education of the poor and the rich. In the developing countries, over $70 \%$ of the population does not have access to the internet technology which is today used by schools to deliver learning and one of the proposals of Illich. Secondly, where the technology is available, it is costly for the poor to pay to acquire and access. Thirdly, student using the web of network type of education and learning method that tends to free students still rely on curricular designed by the school that is reflective of the general curriculum obtainable in the society and approved by the educational authorities.

\section{Freedom: What does it mean?}

Freedom is generally viewed as the condition to be free from any constraints imposed externally. It is rather a condition with minimal constraints and the power to act or speak or think without externally imposed restraints. According to Krishnamurti (1958), "freedom is a state and quality of mind", while Jean-Jacques Rousseau (1979), describe freedom as that which is in the heart of every free man that he takes with him everywhere. However, in education theory, some scholars such as Biesta (2010) prefer to use the word emancipation rather than freedom. Emancipation, Biesta (2010:41) argues is relinquishing "one's authority over someone". It is also seen as immunity from an obligation or duty. However, freedom is multi-faceted and inherently conflicting. The conflict rises from divergent views on the limitations of individual freedom with a society. On one side are those whose view can be termed impractical in a society with a governing rules and regulation and on the other hand are those whose views can be termed compromising that advocate limit to individual freedom. The two groups can be viewed as extremes. These views sometimes represent political spectrums. The conflict between early thinkers and theorists in the freedom discourse has been how much freedom is enough for an individual within a society. Members of the civil society community argue that freedom is inherent and fundamental right of every individual should not be limited in any way and manner irrespective of the governing rules and regulations within the society. Another group viewed more as conservatives argue individual freedom should be subsumed to the societal freedom. In their view, it is quite impractical and unfeasible for an unlimited individual freedom with a governing rules and regulations in the society. These views have shaped the thinking in education theories. However what is obvious is that both groups cannot have it all but accept individual freedom that is within the society and does not infringe on other people's freedom within the society. In view of this, it is important that freedom is recognized as a multi-facet phenomenon that requires holistic perspective and approach.The issue generally is the impact of these views on freedom is having on education. It is generally agreed by the entire spectrum that education plays a vital role in the society and an agent of societal change. As observed by Wilkinson (1994), university education is a change agent and has change as one of its inherent mission. However it has to contend with challenges posed by its contradicting and sometimes competing values. It could be concluded that there is a strong link and relationship between education and freedom.

\section{Education and Technology}

The advent of technology such as Internet in education practice has stirred intense debate and study on its impact on education. According to Mcpheeters (2010:34), the debate could be traced to the "historical approach to education" that had historically considered factors such as reward and punishment as the motivating factors for learning. However the rapid development of technology in education has promoted a new definition of education that incorporates technology as a factor. Acceptance of technology as a factor in education practice debunks the myth of 'fit all' definition of education as historically believed. As the domain of knowledge expands with the growth of technology in education, it becomes evident that knowledge is not only acquired within the four walls of an institution but can be acquired even within the comfort of homes and offices. Also people have the freedom to choose content of what they desire to learn. This no doubt gives individual freedom to choose rather than relying on the rigid curriculum designed by education policy makers and practitioners. This development is support to the theory promoted by Illich that individuals should be given the free hand with the help of technology to choose their form of education and learning. However this individual freedom might not equip the individual with the requisite skills the society needs. Hence, it is still important that whatever learning deployed with the technology should reflect the skills that the society required. While technology has grown as an important factor in education and learning, its impact has thrown up three schools of thought. McPheeters (2010:34) categorized these schools of thought into technophiles (those who view technology as an important tool in education that cannot be ignored), technophobes (those who view technology in education and learning process as alien and destructive should be curtailed) and the cyborg (those with the view that technology is a hybrid of human and machine). One common thing among the technophiles and technophobes schools of thought is that all accept the rapid growth of technology and seeks a control even if it requires 
legislation. The cyborg does not see any reason for the control of the rapid growth of technology, as it is an extension of human activities. It is more comfortable to accept the views of the cyborg that accepts technology as an extension of the human activities. Education policy makers and practitioners have seen this need and deplored education and learning with technology that allows individual freedom. Distance and online education has become very prominent. This form of education and learning is not recognized traditionally as a form of learning. While these forms of education and learning are growing rapidly, there are identified limitations especially in the less developed countries such as infrastructure, cost and availability of resource persons that tends to limit individuals from accessing these forms of education and learning. Another major question is if technology will enhance the learning of all skills including skills that prepares students for self-reliance. However, all trade and profession required importantly for societal development are driven by technology. Finance institutions such as banks and stock markets as well as policy makers in the finance sector rely on technology to discharge their duties. It is quite important that students are exposed to technology during their learning period to enable them utilize it. In view of the above, arguably technology plays a very important role in education and will enhance individual freedom. In addition, it will also prepare students with the societal required skills and pull down the boundary between the formal education and informal education. With technology, it is now possible for creation of virtual classrooms where an individual is free to choose the skill he or she is interested in learning. However, its development will be hampered by factors such as cost, availability of resource persons (online instructors) and infrastructure. These limitations will clearly limit individual freedom in education \& learning; nevertheless, it is important that the technology is generally accepted as a factor that prepares individuals to fit properly into a society that is rapidly influenced by technology. The central question is the role of education as a societal change agent. Taking a holistic view of education theory and practice as well as the rapid influence of technology in education, it is important to examine the role of education as a societal change agent. Hence, in the next section, I shall examine the role of education as a societal change agent.

\section{Education as societal change agent}

Societal change is a shift in the basic structure of a society or when behavior pattern change. This can occur systematically or unsystematically. Societal change is a continuous occurrence. Factors that influence shift in society include politics, economy, education and most recently technology. Education is regarded as the most influential of them and is playing very significant role in societal change. Consequently, efforts at the local, regional and international levels are geared towards standardized formal education that is compulsory and universal. Thus, the universal basic education policy was instituted with a uniform curriculum. According to Tahir (2008) Universal basic education (UBE) policy was introduced in Nigeria to produce graduates that are self-reliant with emphasis on technical and pre-vocational skills that utilizes both formal and informal education systems. However in practice, UBE policy has focused more on formal education system with all effort on making sure there are more enrollments into the traditional school than utilizing other informal educational system available. Also Odia\&Omofonmwan (2007: 83) noted, "Acquisition of Education knowledge is supposed to help us fight against-poverty, ignorance and disease". However they argued that rather than achieve this objective, education has been turned into a tool for exploitation where quality is sacrificed for 'profit'. Such conclusion is always reached in a country where corruption is considered very high in the public sector. The determined effort put into implementation of the universal basic education underline the importance of education as an agent of societal change. However, Begstrom (2010) questioned the benefits and the accessibility of the universal education and argued that universal education that is compulsory limits the right of the child and parents. However the central question is how such education policy can influence a societal change that will empower the people and reduce the rate of poverty in the society. Generally, education through learning can lead to identification of solutions to societal problems including poverty. Some views however tends to restrict where such identification of solution can be found to universities. Kassam (2010) in his analysis of the importance of book learning in the universities concluded that book learning at the universities identifies solutions to societal needs. Also Wilkinson (1994) argued strongly that university is a societal change agent although with some contradictions and challenges. While these views are probably correct, it is important to note that some of the solutions to societal needs and social change were achieved reading or learning outside the university. It contradicts the fact that most trades that provide employment to vast majority of the people in Nigeria are learnt outside the formal standard education. For instance, while the 6-3-3-4 education system adopted in Nigeria to empower the students technologically and provide a platform for self-employment failed to deliver, informal training places delivering the same training are succeeding. Most of the self-employed technicians in Nigeria did not acquire their skills from formal education system with any standard curriculum. In line with this practice, the financial institutions tend to ignore these trades when formulating their credit strategies. Affected more are the women that are denied formal education by old tradition and cultural practices that tends to place limitations on the women. As a result of this, women suffer the scourge of poverty more. In view of this, government at all levels and the civil societies are concentrating more effort in educating the 
women. As observed by Worley, Otto \& Bailey (2010), educating women has immense benefit and very important but usually hidden. In the developing countries such as Nigeria, women's education is assumed among rural dwellers as not important and valuable. However it is generally flawed as the women are known as active players in economic development and can only achieve their potential when they are educated. Education of women will liberate them and give them the freedom to acquire skills that would liberate them from the shackle of poverty.

\section{Conclusion}

Having reviewed the four early philosophers in the field of education and freedom, Adler represents the liberal school of thought while Dewey and Greene are progressive in their thoughts. All agree that freedom should be viewed in the context of discipline, duty and responsibility within the society. However they differ in the approach towards social change and how much education should be influenced by the change. Illich on his side belong to the radical school of thought. He views freedom as total and no strings such as duty; discipline and responsibility should limit such freedom. He does not see any positive benefit the society will gain from an established school system rather a more disjointed society that is more unequal. He proposes that education and learning should be open and accessible through the use of technology. Such proposal would allow individual to choose what and when to learn. Yet, it is imperative to probe further the relationship between education and freedom in the face of rapid societal change and technological development. For instance, the society has witnessed tremendous change within the last three decades with technology as one of its active drivers. However, there are still talks that millions of people are not educated and curriculum does not reflect the changes especially in the developing countries. In addition, the gap between the poor and rich in terms of education has continued to widen while some countries (mainly underdeveloped countries) is finding it difficult to institutionalize education and learning system that reflects the changes in the society and promote individual freedom to choose. One major challenge facing these countries is the issue of financing an institutionalized education that has wide outreach. Hence, most of the countries rely on foreign aids in form of donors, grants and loan to finance institutionalized education. In sum, education is associated with freedom. Without education, it will be difficult to achieve freedom. However, insistence on formal education will place limitation available to individuals. The freedom will give individuals to acquire different skills to liberate from scourge of poverty. Technology has developed as a veritable tool to deliver education that has direct impact on the society. Thus, technology is applied in delivering learning process that allows individuals to choose skills to learn rather than accepting a standard prescribed by policy makers and education practitioners.

[1]. Adler, M., J. (1982).The Paideia $\begin{gathered}\text { Reference } \\ \text { Proposal. New York: Macmilliam. Available at }\end{gathered}$ http://radicalacademy.com/adlerfreedomthrudiscipline.html

[2]. Aluede, R.O.A. (2006). Universal Basic Education in Nigeria: Matters Arising. Journal of Humanities \& Ecology. 20(2). 97-101

[3]. Andreescu, L. (2009). Individual Academic Freedom and aprofessional acts. Education Theory. 59(5).559-578

[4]. Bergstrom, Y. (2010). The Universal Right to Education: Freedom, Equality and Fraternity. Studies in Philosophy \& Education. 29 (2): $167-182$

[5]. Biesta, G. (2010). A New Logic of Emancipation: The Methodology of Jacques Ranciere. Educational Theory. 60(1); 39-59

[6]. Burnett, J. (2007). Tilling the Soil of the European Higher Education Area. Educational Action Research. 15(2): 283-293

[7]. Colburn, A. (2010). The prepared practitioners: Bridging educational theory and practice. University of Washington. Retrieved from www.washington.edu/doit on the 2nd May 2010.

[8]. Dewey, J. (1907). The School and Social Progress. In The School and Society. Chicago: University of Chicago Press.

[9]. Engel, S.M. (2007). Political Education In/As the Practice of Freedom: A Paradoxical Defence from the Perspective of Michael Oaskeshott. Journal of Philosophy of Education. 41(3): 325-345

[10]. Garrison, R. (2000). Theoretical Challenges for Distance Education in the $21^{\text {st }}$ Century: A shift from structural to transactional issues. The international Review of Research in open and distance learning. 1(1). Retrieved from http://www.irrodl.org/index.php/irrodl/article on 25th April, 2010.

[11]. Greene, M. (1988). Freedom, Education and Public Spaces. In The Dialectics of Freedom (pp. 1-23). New York: Teachers College Press.

[12]. Illich, I. (1970). Why We Must Disestablish School. In Deschooling Society. New York: Harper and Row. http://www.preservenet.com/theory/illich.Deschooling/chpl.html

[13]. Heinrich, E., Milne, J. \& Moore, M. (2009). An Investigation into E-tool use for formative assignment assessment: Status and recommendations. Educational Technology \& Society. 12(4): 176-192

[14]. Kassam, K. (2010). Practical Wisdom and Ethical Awareness through Student Experiences of Development. Development in Practice. 20(2): 205-218

[15]. Marshal, J.D. (1996). Michel Foucault: Personal autonomy and education. Kluwer Academic Publishers: London

[16]. Mcpheeters, D. (2010). Cyborg learning theory: Technology in education and the blurring of boundaries. World Future Review. Dec-Jan. Issue

[17]. Nichols, P., Twing, J., \& Mueller, C. D. (2010). Towards Setting Methods as Measurement Processes. Educational Measurement: Issues and Practice. 29(1): 14-24.

[18]. Odia, L.O. \&Omofonmwan, S.I. (2007). Educational System in Nigeria: Problems and Prospects. Journal of Social Sciences. 14(1): 81-86

[19]. Sen, A.K. (1999). Development as Freedom. Oxford University Press: New York

[20]. Todd, S. (2007). Promoting a just education: Dilemmas of rights, freedom and justice. Educational Philosophy and Theory. 36(6). $592-603$ 
[21]. Wilkinson, D. (1994). Transforming the Social Order: The Role of the University in Social Change. Sociological Forum. 9(3). 325341

[22]. Worley, V., Otto, S. \& Bailey, L. E. (2010). Discovering the More: Reading Wright's, Colette's And Cather's Texts as Philosophy of Education. Educational Studies. 46. 192-223

[23]. Dewey, J. (1907). The School and Social Progress. In The School and Society. Chicago: University of Chicago Press.

[24]. Greene, M. (1988). Freedom, Education and Public Spaces.In The Dialectics of Freedom (pp. 1-23). New York: Teachers College

[25]. Press.

[26]. Illich, I. (1970). Why We Must Disestablish School. In DeschoolingSociety.New York: Harper and Row. http://www.preservenet.com/theory/illich.Deschooling/chp1.html 